\title{
Zihinsel Yetersizliği Olan Bireylerle Çalışan Öğretmenlerin Cinsel Eğitime Yönelik Tutumları ve
}

\section{Etik Durumlarının Karşılaştırılması}

\author{
Bora Akdemir ${ }^{1}$, Oktay Taymaz Sarı ${ }^{2}$ \\ ${ }^{1}$ Milli Eğitim Bakanlığl, İstanbul, Türkiye \\ ${ }^{2}$ Özel Eğitim Bölümü, Atatürk Eğitim Fakültesi, Marmara Üniversitesi, İstanbul, Türkiye
}

Sorumlu Yazar: Bora Akdemir, boraakdemir@outlook.com

Makale Türü: Araştırma Makalesi

Bilgilendirme: Bu makale, 2. yazarın danışmanlığında 1. yazar tarafından hazırlanan yüksek lisans tezinden üretilmiş ve daha önce Uluslararası ELMIS 2016 Kongresi’nde sözlü bildiri olarak sunulmuştur.

Kaynak Gösterimi: Akdemir, B., \& Sarı, O. T. (2019). Zihinsel yetersizliği olan bireylerle çalışan öğretmenlerin cinsel eğitime yönelik tutumları ve etik durumlarının karşılaştırılması. Eğitimde Kuram ve Uygulama, 15(3), 267-282. doi: $\underline{10.17244 / \mathrm{eku} .425276}$

\section{Comparison of Attitudes towards Sex Education and Ethical Positions of Teacher Who Work with}

\author{
Intellectually Disabled Individuals \\ Bora Akdemir ${ }^{1}$, Oktay Taymaz Sarı ${ }^{2}$ \\ ${ }^{1}$ Ministry of National Education, Istanbul, Turkey \\ ${ }^{2}$ Department of Special Education, Faculty of Education, Marmara University, Istanbul, Turkey
}

Corresponding Author: Bora Akdemir, boraakdemir@ outlook.com

Article Type: Research Article

Acknowledgement: This article was generated based on the first author's master thesis which was completed under the supervision of second author and presented in the International Congress of ELMIS 2016.

To Cite This Article: Akdemir, B., \& Sarı, O. T. (2019). Zihinsel yetersizliği olan bireylerle çalışan öğretmenlerin cinsel eğitime yönelik tutumları ve etik durumlarının karşılaştırılması. Eğitimde Kuram ve Uygulama, 15(3), 267-282. doi: $\underline{10.17244 / \mathrm{eku} .425276}$ 
2019, 15(3), 267-282

\title{
Zihinsel Yetersizliği Olan Bireylerle Çalışan Öğretmenlerin Cinsel Eğitime Yönelik Tutumları ve Etik Durumlarının Karşılaştırılması *
}

\author{
Bora Akdemir ${ }^{1}$, Oktay Taymaz Sarı ${ }^{2}$ \\ ${ }^{1}$ Milli Eğitim Bakanlığl, İstanbul, Türkiye \\ ORCID: https://orcid.org/0000-0002-1017-9062 \\ ${ }^{2}$ Özel Eğitim Bölümü, Atatürk Ĕgitim Fakültesi, Marmara Üniversitesi, Ístanbul, Türkiye \\ ORCID: https://orcid.org/0000-0002-7350-0909
}

\begin{tabular}{|c|c|}
\hline Öz & Makale Bilgisi \\
\hline $\begin{array}{l}\text { Bu araştırmada zihinsel yetersizliği olan bireylerle çalışan öğretmenlerin cinsel eğitime } \\
\text { yönelik tutumları ile etik durumları arasında bir ilişki olup olmadığı incelenmiştir. Cinsel } \\
\text { eğilimler doğru yönlendirilmediğinde olumsuz sonuçlara yol açabilirler. Zihinsel } \\
\text { yetersizliği olan bireylerde cinsel eğitimin önemi bilinmektedir. Zihinsel yetersizliği olan } \\
\text { bireylerle çalışan öğretmenlerin cinsel eğitime yönelik tutumlarına etki eden faktörlerin } \\
\text { belirlenmesi ve olumsuz olanların ortadan kaldırılarak olumlu olanların desteklenmesinin }\end{array}$ & $\begin{array}{l}\text { Anahtar Kelimeler: Cinsel } \\
\text { eğitim, Etik, Zihinsel } \\
\text { yetersizliği olan birey, İlişkisel } \\
\text { tarama }\end{array}$ \\
\hline bu alandaki sorunları aza indireceği düşünülmektedir. Bu bağlamda etik değerlerin önemi & Makale Geçmişi: \\
\hline ortaya çıkmaktadır. İlişkisel desende tarama modelli bir çalışma olan araştırma & Geliş: 20 Mayıs 2018 \\
\hline kapsamında İstanbul'un 7 ilçesinde toplam 329 öğretmene ulaşılmıştır. Yapılan analizler & Düzeltme: 28 Şubat 2019 \\
\hline sonucunda cinsel eğitime yönelik tutumlarında branş değişkenine göre özel eğitim & Kabul: 28 Eylül 2019 \\
\hline öğretmenleri lehine tüm alt faktörleri kapsayacak şekilde, çevresinde zihinsel yetersizliği & \\
\hline $\begin{array}{l}\text { olan birey bulunma değişkenine göre çevresinde zihinsel yetersizliği olan birey bulunanlar } \\
\text { lehine anlaml } \text { fark bulunmustur. Etik Durum Ölceği verileri analiz edildiğinde }\end{array}$ & Makale Türü: Araştırma \\
\hline $\begin{array}{l}\text { öğretmenlerin idealizm alt boyutuna ilişkin hesaplanan ortalama puanları görecelik alt } \\
\text { boyutu için hesaplanan ortalama puanından oldukça yüksektir. Cinsel eğitime yönelik } \\
\text { tutumlarla etik durumlar arasında ise anlamlı bir fark bulunamamıştır. }\end{array}$ & \\
\hline
\end{tabular}

\footnotetext{
${ }^{*}$ Bu makale, 2. yazarın danışmanlığında 1. yazar tarafından hazırlanan yüksek lisans tezinden üretilmiş ve daha önce Uluslararası ELMİS 2016 Kongresi'nde sözlü bildiri olarak sunulmuştur.
} 


\section{Comparison of Attitudes towards Sex Education and Ethical Positions of Teacher Who Work with}

\section{Intellectually Disabled Individuals}

\begin{tabular}{|c|c|}
\hline Abstract & Article Info \\
\hline $\begin{array}{l}\text { This study was carried out to research whether there is a relationship between the attitudes } \\
\text { towards sex education of teachers who work with intellectually disabled people and their } \\
\text { ethical positions. Sexual inclinations may cause negative results if not directed correctly. } \\
\text { The importance of sex education for intellectually disabled people is a well known fact. It } \\
\text { is believed that determining the factors that affect the attitudes of teachers who work with } \\
\text { intellectually disabled people towards sex education, the elimination of negative factors } \\
\text { and the provision of positive factors will minimize the issues in the cited field. The } \\
\text { importance of ethical values comes to the fore in this context. A total of } 329 \text { teachers were } \\
\text { reached in } 7 \text { districts of Istanbul within the purview of the study, which is a survey model } \\
\text { in relational patterns. As a result of the analysis carried out, a significant difference was } \\
\text { found in favor of special education teachers in their attitudes towards sex education with } \\
\text { regard to the variable field of expertise, and covering all sub factors; and a significant } \\
\text { difference was also found in favor of intellectually disabled people with regard to the } \\
\text { variable: presence of other intellectually disabled people in their social environment. } \\
\text { When the Ethic Position Questionnaire data were analyzed it was found that average } \\
\text { scores of the teachers for the idealism sub-dimension were significantly higher than the } \\
\text { average score calculated for the relativity sub-dimension. A significant difference between } \\
\text { attitudes towards sex education and ethic position was not found. }\end{array}$ & $\begin{array}{l}\text { Keywords: Sexual education, } \\
\text { Ethics, People with intellectual } \\
\text { disability, Relational survey } \\
\text { Article History: } \\
\text { Received: } 20 \text { May } 2018 \\
\text { Revised: } 28 \text { February } 2019 \\
\text { Accepted: } 28 \text { September } 2019\end{array}$ \\
\hline
\end{tabular}




\section{Giriş}

Zihinsel yetersizlik tanımlarına bakıldığında, bilişsel, motor, iletişim, öz bakım, sosyal beceriler gibi temel gelişim alanlarında yaşıtlarından anlamlı derecede gerilik, uyumsal davranışlarda sınıllılıklar ve yetersizliği 18 yaşından önce olması gibi temel unsurların ortak olduğunu görebiliriz (Eripek, 2009; Özel Eğitim Hizmetleri Yönetmeliği, 2012; Seyyar, 2008; Sucuoğlu, 2009). İlgili çalışmalarda pek çok alanda gelişimsel gerilikten bahsedilirken temel bir gelişim alanı olan cinsel gelişim alanında anlamlı bir gerilik olduğu ise ifade edilmemektedir. Bunun yanı sıra bazı çalışmalarda ise zihinsel yetersizliğe sahip olan bireylerin cinsel gelişim alanında yaşıtlarından anlamlı ölçüde farklılaşmadığı ifade edilmektedir (Tepper, 2001; Yurdakul, 1999).

Cinsellik her bireyi ilgilendiren, hem beden hem de ruh sağlığı açısından insan üzerinde büyük etkileri olan, bununla birlikte çözülmesi zor toplumsal sorunlara neden olabilen hassas bir konudur ve sağlığımızın en temel olgularından biridir (Poroy, 2005). Cinselliğin algılanışı toplumlara ve hatta bireylere göre bazı farklılıklar göstermektedir. Bazı kişiler cinselliği, cinsel birleşme ve üreme bazı kişiler ise cinsel açıdan uyarılmış kişilerin gösterdiği davranışlar olarak algılamaktadır (Özgüven, 1997).

Cinsel eğitim birçok uzmana göre bebeklik döneminden başlayarak yetişkinlik dönemine kadar süren bir eğitim sürecidir. Bireyin kendi vücudunu ve cinsel özelliklerini tanıması, aynı şekilde karşı cinsi tanıması, cinsel kimlikleri öğrenmesi ve temel cinsel güdülerini kontrol altına alması, kendisini bu anlamda koruyabilmesi gibi konuları içermektedir. Bu eğitim duygusal gelişim ve toplumsal kabulde çok önemli bir rol oynamaktadır (Akay, 1999, Başaran, 1998).

Zihinsel düzeylerinden bağımsız olarak tüm insanlar cinsiyetleri ile doğarlar ve genellikle cinsiyetlerinin onlara verdiği rollerle yaşarlar. Cinsel gelişim alanının karmaşıklığı ve diğer geliş̧im alanlarıyla ilişkileri düşünüldügünde özel gereksinimli olsun ya da olmasın tüm insanların cinsel eğitime ihtiyaçları bulunmaktadır. Zaten toplumun belli kesimlerinde tartışmalı olan cinsel eğitim konusu söz konusu zihinsel yetersizliği olan bireyler olduğunda daha da karmaşık bir hal almaktadır (Counwenhoven, 2001; Mandan-Sürücü, 2009; Myers, 2006) Zihinsel yetersizliği olan bireyler cinsel gelişimlerini ve buna dayalı ihtiyaçlarını sağlıklı ve doğru tarzda karşılayabilmeleri için yetişkinlerin cinsel eğitimine ihtiyaç duyarlar (Jahoda \& Pownall, 2014).

Zihinsel yetersizliği olan bireylerin aileleri bakımından cinsel eğitim ihtiyacı genellikle kızlarda regl dönemlerinin başlaması ya da cinsel istismar gibi durumların yaşanmasıyla gündeme gelmektedir (Counwenhoven, 2001; Mandan-Sürücü, 2009; Yohalem, 1995). Cinsel eğitim ilk olarak aileden sonrasında ise öğretmen tarafından verilmektedir. Bunun yanı sıra medya, internet, akranların yanı sıra bireyler cinselliği kendi deneyimlerinde de öğrenebilmektedirler (Couwenhoven, 2001). Zihinsel yetersizliği olan bireyler açısından en çok tercih edilen kaynak ise özel eğitim öğretmenleridir. Tüm bu kaynaklara rağmen cinsel bilgilerin zihinsel yetersizliği olan bireyler tarafindan edinilmesi oldukça zor olduğu bilinmektedir. Bu durum da yaşamın geneli, cinsel roller ve istismar gibi konularda ciddi problemler üretebilmektedir (Ademi, Pillaty, \& Esterhuizen, 2013).

Özel gereksinimli bireylere verilecek cinsel eğitim programlarının içeriğinde geniş olarak şu konular yer almaktadır: Beden bölümleri ve görevleri, cinsiyet bilgisi/cinsel kimlik, mastürbasyon, adet, cinsel ilişki, flört, arkadaşlık ve dostluk, gebelik, doğum ve doğum kontrolü, cinsel yolla bulaşan hastalıklar, sosyal becerilerin öğretimi, eşcinsellik, mahremiyet, cinsel istismar/taciz (Ailey, Marks, Crips, \& Hahn, 2003; Blanchett \& Wolfe, 2002; Brantlinger, 1985; Coleman \& Murph, 1980; Counwenhoven, 2001; Hall, Morris, \& Barker, 1973; Edmonson \& Wish, 1975; Garwood \& McCabe, 2000; McCabe, Cummins, \& Deeks, 1999; Whitehouse \& McCabe, 1997; Yohalem, 1995).

Tutumlar, bireylere, topluluklara, nesne ya da fikirlere yönelik oldukça kararlılık gösteren önceden şekillenmiş duygu, düşünce ve inançlar bütünüdür. Tutumlar, toplumsal değerler, ait olunan alt grup özellikleri, siyasal görüş, dini inanışlar, önceki yaşantılar gibi birçok etmenden etkilenmektedirler (Özyürek, 2009).

Cinsel eğitime yönelik öğretmen tutumlarına baktığımızda zihinsel yetersizliği olan bireylerle çalışan öğretmenlerin bir kısmı olumlu bir kısmı ise olumsuz tutum sergilemektedirler. Bu tutumların oluşumunda bilgi düzeyi, mesleki deneyim, toplumsal değerler, inanışlar gibi birçok faktörün etkili olduğu düşünülmektedir (Yavuz, Tekcan, \& Vural-Batık, 2013). 
Konuya ebeveynler yönünden baktığımızda ise ebeveynlerin bazılarının olumsuz tutum sergilediklerini söyleyebiliriz. Birçok ebeveyn bu konuyu yok sayma ya da bastırma eğilimindedir. Birçok aile cinselliği tehlike olarak görmekte ve bu konuyu öğrenmesini kısıtlayarak çocuğunu koruduğunu düşünmektedir. Zihinsel yetersizliği olan bireylerin cinsel ihtiyaçlarının toplumsal kabulünün olamayacağının düşünülmesi bu yaklaşımda önemli rol oynar (Sayın, 2007). Aileler çocuklarının büyüdügünü kabullenişte zorlanmakta, bu konuda yapılacakların bunu denemeye yol açabileceği, gebelik gibi istenmeyen sonuçlara yol açabileceğini düşünmektedirler. Bu gerekçelerle aileler cinsel eğitime yönelik engelleyici tutumlar takınabilmektedirler (Mandan-Sürücü, 2009; Myers, 2006; Yohalem, 1995).

Cinsel eğitime yönelik öğretmen tutumlarını belirleyen faktörlerden bir tanesi de etik durumlar olabilir. Yapılan araştırmalar sonucunda etik yargıları belirleyen temel etmenler ortaya konulmuştur. Bunlardan en baskın olanları idealizm ve göreciliktir. İdealizm eğilimi gösteren bireyler doğru sonuçlara ulaşmak için doğru eylemleri yapmak gerektiğine inanırlar. Karar verirken olumsuz sonuca yol açmama ve başkalarına zarar vermeme temel güdüsüyle hareket ederler. Bu bakışla idealizm eğilimi düşük olan birisi, istediği sonuçlara ulaşma için gerektiğinde başkalarına zarar verecek kararlar vermekten de çekinmeyebilir. Görecilik eğilimi baskın olan bireyler evrensel ve genel geçer ahlaki kuralların varlı̆̆ını reddederler. Onlara göre ahlak kuralları zaman ve mekanın, içinde bulunulan durumun bir uzantısı olarak ortaya çıkmaktadır. Başka alt boyutlar olmakla birlikte bu iki temel faktör etik durumların tanımlanmasında başat rol oynamaktadır (Forsyth, 1980; Yazıc1, 2010, s. 1004).

Zihinsel yetersizliği olan bireylerle çalışan öğretmenlerin cinsel eğitime yönelik tutumlarına etki eden faktörlerin belirlenmesi ve olumsuz olanların ortadan kaldırılması önemli bir konudur. Bu tutumları belirlemek, öğretmenlerin etik durumlarıyla ve diğer bazı değişkenlerle ilişkisini ortaya koymak bu bağlamda işlev kazanabilir. Ayrıca yapılan kaynak taramasında zihinsel yetersizliği olan bireylerle çalışan öğretmenlerin cinsel eğitime yönelik tutumlarını etik durumlarıyla karşılaştıran bir çalışmaya rastlanmamıştır. Bu noktada alanyazına katkı sunulacağ1 düşünülmektedir. $\mathrm{Bu}$ araştırmanın amacı, zihinsel yetersizliği olan bireylerle çalışan öğretmenlerin cinsel eğitime yönelik tutumları ile etik durumları arasında bir ilişki olup olmadığının belirlenmesidir. Bu bağlamda şu sorulara yanıtlar aranmıştır;

1. Zihinsel yetersizliği olan bireylerle çalışan öğretmenlerin cinsel eğitime yönelik tutum puanlarl; yaş, cinsiyet, öğrenim görülen alan, mesleki deneyim, cinsel eğitime yönelik eğitim alıp almaması, çevresinde zihinsel yetersizliği olan bireyin bulunup bulunmaması gibi bazı değişkenlere göre anlamlı bir şekilde farklılaşmakta mıdır?

2. Zihinsel yetersizliği olan bireylerle çalışan öğretmenlerin etik durumları; yaş, cinsiyet, öğrenim görülen alan, mesleki deneyim, cinsel eğitime yönelik eğitim alıp almaması, çevresinde zihinsel yetersizliği olan bireyin bulunup bulunmaması gibi bazı değişkenlere göre anlamlı bir şekilde farklılaşmakta mıdır?

3. Zihinsel yetersizliği olan bireylerle çalışan öğretmenlerin cinsel eğitime yönelik tutumları ile etik durumları arasında anlamlı bir ilişki var mıdır?

\section{Araştırma Modeli}

\section{Yöntem}

$\mathrm{Bu}$ araştırma zihinsel yetersizliği olan bireylerle çalışan öğretmenlerin cinsel eğitime yönelik tutumları ile etik durumları arasındaki ilişkiyi belirlemeye yönelik yapılandırılmış ilişkisel desende tarama modelli bir çalışmadır. İlişkisel tarama modelleri, iki ve daha çok sayıdaki değişken arasında birlikte değişim ve/veya derecesini belirlemeyi amaçlayan araştırma modelleridir (Karasar, 2000).

\section{Çalışma Grubu}

Çalışma grubunu, İstanbul ilinin sekiz ilçesinde (Kadıköy, Ataşehir, Beykoz, Ümranıye, Şişli, Kâğıthane, Zeytinburnu ve Bakırköy) MEB'e bağlı özel eğitim okullarında görev yapmakta olan ve zihinsel yetersizliği olan bireylerle çalışan, özel eğitim ve diğer branşlardan öğretmenler oluşturmuştur. Bu grup içerisinden 329 kişi tesadüfi oransız küme örnekleme yöntemi ile seçilmiştir. İlgili okullara 1000 veri toplama araciyla gidilmiş bunlardan 354 tanesi geri dönmüş ve bu araçlardan 329 tanesi eksizsiz doldurulduğu için geçerli sayılmıştır. Katılımcıların \%74'ü kadın, \%24'ü erkektir.

\section{Verilerin Toplama Araçları}

Araştırmada katılımcıların demografik bilgilerini almak amacıyla kişisel bilgi formu, zihinsel yetersizliği olan bireylerle çalışan öğretmenlerin cinsel eğitime yönelik tutumlarını ölçmek amacıyla Serin, Girli ve Doğru (2013) tarafindan geliştirilen Zihinsel Yetersizliği Olan Bireylerle Çalışan Öğretmenlerin Cinsel Eğitime Yönelik Tutumları 
Ölçeği ve etik durumlarını ölçmek için ise Forsyth (1980) tarafından geliştirilen, Yazıcı ve Yazıcı (2010) tarafından dilimize uyarlanan Etik Durum Ölçeği kullanılmıştır.

Araştırmacı tarafından geliştirilen Kişisel Bilgi Formu (KBF) öğretmen adaylarının demografik bilgilerini içerecek şekilde düzenlenmiştir. Formda yer alan bilgiler şunlardır: yaş, cinsiyet, öğrenim görülen alan, mesleki deneyim, cinsel eğitime yönelik eğitim alıp almama, çevresinde zihinsel yetersizliği olan birey bulunup bulunmama, medeni durum, 18 yaşına kadar yaşadığ 1 yerleşim yeri bilgileri yer almıştır.

Zihinsel Yetersizliği Olan Bireylerle Çalışan Öğretmenlerin Cinsel Eğitime Yönelik Tutumları Ölçeği (CEYTÖ) Serin, Girli ve Doğru (2013) tarafından geliştirilmiştir. Ölçeğin güvenirlik ve geçerlik çalışması sonucunda Cronbach $\propto$ güvenirliği .90 bulunmuştur. Ölçek 34 maddeden oluşmaktadır ve 4, 6, 7, 8, 10, 12 ve 13. sorular ters puanlanmaktadır. Yapılan açıklayıcı faktör analizi neticesinde altı faktörlü bir yapı ortaya çıkmıştır. Bunlar; akran ilişkileri, beden imgesi, gereklilik, olumsuz etki, cinsiyet ve öğretmen yeterliliğidir. Ölçekten alınabilecek en düşük puan 34, en yüksek puan ise 170 'dir. Ölçekten alınan puanların artması, zihinsel yetersizliği olan bireylerle çalışan öğretmenlerin cinsel eğitime yönelik tutumlarının arttığını göstermektedir. Yapılan geçerlilik çalışmasında testin toplam puanlarına göre oluşturulan alt $\% 27$ ve üst $\% 27^{\prime}$ lik gruplar madde ortalama puanları arasındaki farklar bağımsız örneklem $\mathrm{t}$-testi kullanılarak sinandığında ölçeğin $\mathrm{t}=28.24$ ve değerlerinin anlamlı $(\mathrm{p}=.000)$ olduğu görülmektedir. Dolayısıyla ölçeğin geçerliğine ilişkin yapılan madde analizi bulguları da geçerliğini destekler niteliktedir.

Forsyth (1980) tarafindan geliştirilen ve 2010 yılında Yazıcı ve Yazıcı tarafından dilimize uyarlanarak geçerlik güvenirlik çalışması yapılan Etik Durum Ölçeği'de (EDÖ) likert tipi 20 madde bulunmaktadır. EDÖ’nün geçerlilik ve güvenirliği için yapılan çalışmada 593 kişilik bir örnekleme ulaşılmıştır. Yap1 geçerliliğini değerlendirmek için ölçeğin maddeleri temel bileşenler çözümlemesi yoluyla faktör çözümlemesi uygulanmıştır. Sonuçlar toplam varyansın \% 51.07'sını açıklayan iki faktörlü bir yapı ortaya koymuştur. Cronbach alfa yöntemiyle ölçülen iç tutarlılık güvenirliği toplam 19 madde için .90 , idealizm faktörü için .92 ve görecilik faktörü için .84 olarak bulunmuştur. Sonuç olarak, EDÖ'nin Türkçe formuna ilişkin bulgular ölçeğin geçerli ve güvenilir olduğunu göstermiştir (Yazıcı \& Yazıc1, 2010).

\section{Verilerin Analizi}

Araştırmaya katılan öğretmenlerden elde edilen verilerin tümü (Kişisel Bilgi Formu, Cinsel Eğitime Yönelik Tutumlar Ölçeği ve Etik Durum Ölçeği) SPSS 20.0 for Windows paket programı ile analize tabi tutulmuştur. Araştırmanın amacına uygun olarak, toplanan verilerle şu analizler yapılmıştır:

a) Örneklemi oluşturan öğretmenlerin demografik özelliklerini özetlemek açısından değişkenlerinin frekans (f) ve yüzdeleri (\%) hesaplanmıştır.

b) Öğretmenlerin demografik özelliklerine bağlı olarak Cinsel Eğitime Yönelik Tutumlar Ölçeği ve Etik Durum Ölçeği alt boyutlarına ilişkin algı düzeylerinde anlamlı farklılaşmalar olup olmadığını araştırmak üzere ilişkisiz (bağımsız) gruplar t-testi ve tek yönlü varyans analizi (ANOVA) uygulanmıştır. Tek yönlü varyans analizlerinde anlamlı fark bulunduğunda, farkın hangi gruplar arasında olduğunu araştırmak üzere post-hoc Scheffe testi yapılmıştır.

c) Öğretmenlerin öğrenim durumlarına bağlı olarak Cinsel Eğitime Yönelik Tutumlar Ölçeği ve Etik Durum Ölçeği alt boyutlarına ilişkin algı düzeylerinde anlamlı farklılaşmalar olup olmadığını araştırmak üzere parametrik olmayan Kruskal Wallis-H testi uygulanmıştır. Non-parametrik testin seçilmesinin sebebi normal dağılım gözlenmemesidir.

d) Öğretmenlerin, cinsel eğitime yönelik tutumlar ile etik durumları arasındaki ilişkileri araştırmak üzere Pearson momentler çarpımı korelasyonu katsayıları hesaplanmıştır.

e) Tüm istatistiksel hesaplamalarda anlamlılık düzeyi .05 olarak kabul edilmiştir.

\section{Bulgular}

Cinsel eğitime yönelik tutum puanlarıyla demografik değişkenler karşılaştırıldığında; yaş, cinsiyet, öğrenim durumu, kıdem, cinsel eğitimle ilgili ders ve/veya hizmet içi eğitim alma, yaşanılan yerleşim birimi değişkenlerinde anlamlı bir farkın bulunmadığı görülmüştür. Branş, çevresinde zihinsel yetersiliği olan birey bulunma ve çevresinde cinsel 
istismara uğramış birisi bulunma değişkenlerinde ise bazı alt değişkenlerde anlamlı farklılık bulunduğu tespit edilmiştir. Değişkenler için yapılan analizlerde dağılım normalliğinin olmadığı anlaşılmıştır.

Tablo 1. CEYTÖ puanlarının branş değişkenine göre farklılaşıp

farklılaşmadığını belirlemek üzere yapılan ANOVA testi sonuçları

\begin{tabular}{|c|c|c|c|c|c|c|c|c|c|c|}
\hline & $f, \bar{X}$ ve ss Değerleri & & & & & ANOVA & Sont & uçları & & \\
\hline Puan & Grup & $N$ & $\overline{\mathrm{X}}$ & ss & Var. Kay. & $K T$ & $S d$ & $K O$ & $F$ & $p$ \\
\hline \multirow[t]{4}{*}{ Akran İlişkileri } & Özel eğitim öğretmeni & 142 & 3,57 & 0,92 & G. Arası & 4,30 & 2 & 2,15 & 2,40 & 0,092 \\
\hline & Sınıf öğretmeni & 119 & 3,32 & 0,97 & G. İçi & 292,09 & 326 & 0,90 & & \\
\hline & Diğer & 68 & 3,52 & 0,96 & Toplam & 296,39 & 328 & & & \\
\hline & Toplam & 329 & 3,47 & 0,95 & & & & & & \\
\hline \multirow[t]{4}{*}{ Beden İmgesi } & Özel eğitim öğretmeni & 142 & 4,36 & 0,67 & G. Arası & 4,49 & 2 & 2,24 & 4,69 & $0,010^{*}$ \\
\hline & Sınıf öğretmeni & 119 & 4,10 & 0,74 & G. İçi & 155,84 & 326 & 0,48 & & \\
\hline & Diğger & 68 & 4,25 & 0,64 & Toplam & 160,33 & 328 & & & \\
\hline & Toplam & 329 & 4,24 & 0,70 & & & & & & \\
\hline \multirow[t]{4}{*}{ Gereklilik } & Özel eğitim öğretmeni & 142 & 4,14 & 0,79 & G. Arası & 8,49 & 2 & 4,25 & 6,49 & $0,002 *$ \\
\hline & Sınıf öğretmeni & 119 & 3,86 & 0,81 & G. İçi & 213,45 & 326 & 0,66 & & \\
\hline & Diğer & 68 & 3,76 & 0,85 & Toplam & 221,94 & 328 & & & \\
\hline & Toplam & 329 & 3,96 & 0,82 & & & & & & \\
\hline \multirow[t]{4}{*}{ Olumsuz Etki } & Özel eğitim öğretmeni & 142 & 4,03 & 0,72 & G. Arası & 2,22 & 2 & 1,11 & 2,05 & 0,131 \\
\hline & Sınıf öğretmeni & 119 & 3,86 & 0,76 & G. İçi & 176,47 & 326 & 0,54 & & \\
\hline & Diğer & 68 & 3,87 & 0,72 & Toplam & 178,69 & 328 & & & \\
\hline & Toplam & 329 & 3,94 & 0,74 & & & & & & \\
\hline \multirow[t]{4}{*}{ Cinsiyet } & Özel eğitim öğretmeni & 142 & 3,63 & 0,79 & G. Arası & 2,61 & 2 & 1,30 & 2,20 & 0,112 \\
\hline & Sınıf öğretmeni & 119 & 3,43 & 0,75 & G. İçi & 193,13 & 326 & 0,59 & & \\
\hline & Diğer & 68 & 3,50 & 0,76 & Toplam & 195,74 & 328 & & & \\
\hline & Toplam & 329 & 3,53 & 0,77 & & & & & & \\
\hline \multirow{4}{*}{$\begin{array}{l}\text { Öğretmen } \\
\text { Yeterliliği }\end{array}$} & Özel eğitim öğretmeni & 142 & 3,83 & 0,78 & G. Arası & 8,04 & 2 & 4,02 & 7,27 & $0,001 *$ \\
\hline & Sınıf öğretmeni & 119 & 3,48 & 0,71 & G. İçi & 180,18 & 326 & 0,55 & & \\
\hline & Diğer & 68 & 3,65 & 0,72 & Toplam & 188,22 & 328 & & & \\
\hline & Toplam & 329 & 3,67 & 0,76 & & & & & & \\
\hline \multirow{4}{*}{$\begin{array}{lr}\text { Cinsel } & \text { Eğitime } \\
\text { İlişkin } & \text { Tutum } \\
\text { Ölçeği } & \end{array}$} & Özel eğitim öğretmeni & 142 & 3,93 & 0,59 & G. Arası & 4,27 & 2 & 2,14 & 6,68 & $0,001 *$ \\
\hline & Sınıf öğretmeni & 119 & 3,68 & 0,52 & G. İçi & 104,17 & 326 & 0,32 & & \\
\hline & Diğger & 68 & 3,76 & 0,58 & Toplam & 108,44 & 328 & & & \\
\hline & Toplam & 329 & 3,80 & 0,58 & & & & & & \\
\hline
\end{tabular}

*Fark p<.05 düzeyinde anlamlidlr.

Zihinsel yetersizliği olan bireylerle çalışan öğretmenlerin branşlarına bağlı olarak cinsel eğitime yönelik tutumlarında anlamlı bir farklılık olup olmadığı tek yönlü varyans analizi (ANOVA) ile incelenmiş ve branş değişkeninin ölçeğin geneli ile beden imgesi, gereklilik ve öğretmen yeterliliği boyutları bakımından anlamlı bir farklılaşmaya neden olduğu görülmüştür. Hangi branşlar arasında anlamlı farklılaşmalar olduğunu araştırmak üzere yapılan post-hoc Scheffe testi sonuçları ise aşağıda, Tablo 2'de verilmiştir. 
Tablo 2. CEYTÖ puanlarının branş değişkenine göre hangi gruplar arasında farklılaştığını belirlemek üzere yapılan Scheffe testi sonuçları

\begin{tabular}{|c|c|c|c|c|c|}
\hline Puan & Gruplar (i) & Gruplar (j) & $\bar{X}_{\mathrm{i}^{-}} \bar{X}_{\mathrm{j}}$ & $\mathrm{Sh}_{\overline{\mathrm{x}}}$ & $p$ \\
\hline \multirow[t]{6}{*}{ Beden İmgesi } & \multirow[t]{2}{*}{ Özel eğitim öğretmeni } & Sınıf öğretmeni &, $263^{*}$ & 0,086 & 0,010 \\
\hline & & Diğer & 0,118 & 0,102 & 0,515 \\
\hline & \multirow[t]{2}{*}{ Sınıf öğretmeni } & Özel eğitim öğretmeni &,$- 263 *$ & 0,086 & 0,010 \\
\hline & & Diğger & $-0,146$ & 0,105 & 0,384 \\
\hline & \multirow[t]{2}{*}{ Diğer } & Özel eğitim öğretmeni & $-0,118$ & 0,102 & 0,515 \\
\hline & & Sinıf öğretmeni & 0,146 & 0,105 & 0,384 \\
\hline \multirow[t]{6}{*}{ Gereklilik } & \multirow[t]{2}{*}{ Özel eğitim öğretmeni } & Sınıf öğretmeni & $280 *$ & 0,101 & 0,022 \\
\hline & & Diğer &, $380 *$ & 0,119 & 0,007 \\
\hline & \multirow[t]{2}{*}{ Sınıf öğretmeni } & Özel eğitim öğretmeni &,$- 280 *$ & 0,101 & 0,022 \\
\hline & & Diğer & 0,100 & 0,123 & 0,717 \\
\hline & \multirow{2}{*}{ Diğer } & Özel eğitim öğretmeni &,$- 380 *$ & 0,119 & 0,007 \\
\hline & & Sınıf öğretmeni & $-0,100$ & 0,123 & 0,717 \\
\hline \multirow{6}{*}{$\begin{array}{l}\text { Öğretmen } \\
\text { Yeterliliği }\end{array}$} & \multirow[t]{2}{*}{ Özel eğitim öğretmeni } & Sınıf öğretmeni &, $352 *$ & 0,092 & 0,001 \\
\hline & & Diğer & 0,179 & 0,11 & 0,265 \\
\hline & \multirow[t]{2}{*}{ Sınıf öğretmeni } & Özel eğitim öğretmeni &,$- 352 *$ & 0,092 & 0,001 \\
\hline & & Diğer & $-0,173$ & 0,113 & 0,311 \\
\hline & \multirow[t]{2}{*}{ Diğer } & Özel eğitim öğretmeni & $-0,179$ & 0,11 & 0,265 \\
\hline & & Sinıf öğretmeni & 0,173 & 0,113 & 0,311 \\
\hline \multirow{6}{*}{$\begin{array}{l}\text { Cinsel Eğitime } \\
\text { İlişkin Tutum } \\
\text { Ölçeği }\end{array}$} & \multirow{2}{*}{ Özel eğitim öğretmeni } & Sınıf öğretmeni &, $252 *$ & 0,07 & 0,002 \\
\hline & & Diğger & 0,169 & 0,083 & 0,129 \\
\hline & \multirow[t]{2}{*}{ Sınıf öğretmeni } & Özel eğitim öğretmeni &,$- 252 *$ & 0,07 & 0,002 \\
\hline & & Diğger & $-0,083$ & 0,086 & 0,630 \\
\hline & \multirow[t]{2}{*}{ Diğer } & Özel eğitim öğretmeni & $-0,169$ & 0,083 & 0,129 \\
\hline & & Sinıf öğretmeni & 0,083 & 0,086 & 0,630 \\
\hline
\end{tabular}

*Fark $p<.05$ düzeyinde anlamlidlr.

Yapılan analiz neticesinde öğretmenlerin, cinsel eğitime ilişkin genel tutumlarının branşlarına göre farklılaştığı bulunmuştur $[\mathrm{F}(2 ; 326)=6,68$ ve $\mathrm{p}<0,05]$. Post-hoc Scheffe testine göre, özel eğitim öğretmenlerinin cinsel eğitime ilişkin genel tutumları (puanları) diğer branşlardan daha olumlu bulunmuştur.

Tablo 3. CEYTÖ puanlarının çevrelerinde zihinsel yetersizliğe sahip birey olması değişkenine göre farklılaşıp farklılaşmadığını belirlemek üzere yapılan t testi sonuçları

\begin{tabular}{|c|c|c|c|c|c|c|c|c|}
\hline \multirow{2}{*}{ Puan } & \multirow{2}{*}{ Gruplar } & \multirow{2}{*}{$N$} & \multirow{2}{*}{$\bar{X}$} & \multirow{2}{*}{ ss } & \multirow{2}{*}{$\mathrm{Sh}_{\overline{\mathrm{x}}}$} & \multicolumn{3}{|c|}{ t Testi } \\
\hline & & & & & & $t$ & $S d$ & $p$ \\
\hline \multirow[t]{2}{*}{ Akran İlişkileri } & Evet & 212 & 3,56 & 0,93 & 0,06 & 2,24 & 327 & $0,026 *$ \\
\hline & Hayır & 117 & 3,31 & 0,98 & 0,09 & & & \\
\hline \multirow[t]{2}{*}{ Beden İmgesi } & Evet & 212 & 4,28 & 0,70 & 0,05 & 1,31 & 327 & 0,191 \\
\hline & Hayır & 117 & 4,18 & 0,70 & 0,07 & & & \\
\hline \multirow[t]{2}{*}{ Gereklilik } & Evet & 212 & 4,00 & 0,82 & 0,06 & 1,26 & 327 & 0,210 \\
\hline & Hayır & 117 & 3,88 & 0,83 & 0,08 & & & \\
\hline \multirow[t]{2}{*}{ Olumsuz Etki } & Evet & 212 & 4,00 & 0,72 & 0,05 & 1,98 & 327 & $0,049 *$ \\
\hline & Hayır & 117 & 3,83 & 0,76 & 0,07 & & & \\
\hline \multirow[t]{2}{*}{ Cinsiyet } & Evet & 212 & 3,57 & 0,79 & 0,05 & 1,37 & 327 & 0,173 \\
\hline & Hayır & 117 & 3,45 & 0,74 & 0,07 & & & \\
\hline \multirow[t]{2}{*}{ Öğretmen Yeterliliği } & Evet & 212 & 3,70 & 0,76 & 0,05 & 1,06 & 327 & 0,288 \\
\hline & Hayır & 117 & 3,61 & 0,76 & 0,07 & & & \\
\hline Cinsel Eğitime İlişkin & Evet & 212 & 3,85 & 0,58 & 0,04 & 2,15 & 327 & $0,032 *$ \\
\hline Tutum Ölçeği & Hayır & 117 & 3,71 & 0,56 & 0,05 & & & \\
\hline
\end{tabular}


Öğretmenlerin \%64'ü çevrelerinde zihinsel yetersizliğe sahip birey olduğunu, \%36'sı ise olmadığını belirtmiştir. Zihinsel yetersizliği olan bireylerle çalışan öğretmenlerin çevrelerinde zihinsel yetersizliği olan birey olmasına bağlı olarak cinsel eğitime yönelik tutumlarında anlamlı bir farklılık olup olmadığı bağımsız gruplar t-testi ile incelenmiş ve ölçeğin geneli ile akran ilişkileri ve olumsuz etki alt boyutları bakımından çevresinde zinsel yetersizliğe sahip birey olduğunu söyleyenler lehine anlamlı bir farklılaşmaya neden olduğu görülmüştür (Tablo 3) $(\mathrm{p}<.05)$.

Tablo 4. CEYTÖ puanlarının çevrelerinde cinsel istismara uğramış birey olması değişkenine göre farklılaşıp farklılaşmadığını belirlemek üzere yapılan t testi sonuçları

\begin{tabular}{|c|c|c|c|c|c|c|c|c|}
\hline \multirow{2}{*}{ Puan } & \multirow{2}{*}{ Gruplar } & \multirow{2}{*}{$N$} & \multirow{2}{*}{$\bar{X}$} & \multirow{2}{*}{ ss } & \multirow{2}{*}{$\mathrm{Sh}_{\overline{\mathrm{x}}}$} & \multicolumn{3}{|c|}{ t Testi } \\
\hline & & & & & & $t$ & $S d$ & $p$ \\
\hline \multirow[t]{2}{*}{ Akran İlişkileri } & Evet & 73 & 3,75 & 0,95 & 0,11 & 2,85 & 327 & $0,005^{*}$ \\
\hline & Hayır & 256 & 3,39 & 0,94 & 0,06 & & & \\
\hline \multirow[t]{2}{*}{ Beden İmgesi } & Evet & 73 & 4,33 & 0,69 & 0,08 & 1,19 & 327 & 0,236 \\
\hline & Hayır & 256 & 4,22 & 0,70 & 0,04 & & & \\
\hline \multirow[t]{2}{*}{ Gereklilik } & Evet & 73 & 4,05 & 0,96 & 0,11 & 1,06 & 327 & 0,289 \\
\hline & Hayır & 256 & 3,94 & 0,78 & 0,05 & & & \\
\hline \multirow[t]{2}{*}{ Olumsuz Etki } & Evet & 73 & 3,96 & 0,83 & 0,10 & 0,33 & 327 & 0,745 \\
\hline & Hayır & 256 & 3,93 & 0,71 & 0,04 & & & \\
\hline \multirow[t]{2}{*}{ Cinsiyet } & Evet & 73 & 3,82 & 0,82 & 0,10 & 3,66 & 327 & $0,000 * *$ \\
\hline & Hayır & 256 & 3,45 & 0,74 & 0,05 & & & \\
\hline \multirow[t]{2}{*}{ Öğretmen Yeterliliği } & Evet & 73 & 3,80 & 0,79 & 0,09 & 1,76 & 327 & 0,080 \\
\hline & Hayır & 256 & 3,63 & 0,75 & 0,05 & & & \\
\hline Cinsel Eğitime İlişkin & Evet & 73 & 3,95 & 0,63 & 0,07 & 2,55 & 327 & $0,011^{*}$ \\
\hline Tutum Ölçeği & Hayır & 256 & 3,76 & 0,55 & 0,04 & & & \\
\hline
\end{tabular}

*Fark $p<.05$ düzeyinde ve **fark $p<.001$ düzeyinde anlamlıdır.

Zihinsel yetersizliği olan bireylerle çalışan öğretmenlerin çevrelerinde cinsel istismara uğramış birey olmasına bağlı olarak cinsel eğitime yönelik tutumlarında anlamlı bir farklılık olup olmadığı bağımsız gruplar t-testi ile incelenmiş ve ölçeğin geneli ile akran ilişkileri ve cinsiyet alt boyutları bakımından çevresinde cinsel istismara uğramış birey bulunanlar lehine anlamlı bir farklılaşmaya neden olduğu görülmüştür (Tablo 4) ( $<$ <.05).

Etik durumlar incelenirken önce araştırmaya katılan ve zihinsel yetersizliği olan bireylerle çalışan öğretmenlerin etik durum düzeyleri incelenmiş daha sonra ise çeşitli değişkenlere göre etik durumlarında farklılaşmalar olup olmadığı araştırılmıştır.

Tablo 5. EDÖ boyutlarına ait betimsel istatistikler

\begin{tabular}{lcccc}
\hline Boyutlar & $\mathrm{N}$ & $\bar{X}$ & ss & $\mathrm{Sh}_{\overline{\mathrm{x}}}$ \\
\hline İdealizm & 329 & 4,10 & 0,46 & 0,03 \\
Görecelik & 329 & 3,43 & 0,68 & 0,04 \\
\hline
\end{tabular}

Tablo 5.'den de görüleceği üzere, araştırmaya katılan öğretmenlerin idealizm alt boyutuna ilişkin hesaplanan ortalama puanları ( $\bar{X}_{\text {İdealizm=4,10 } \pm 0,46)}$ görecelik alt boyutu için hesaplanan ortalama puanından

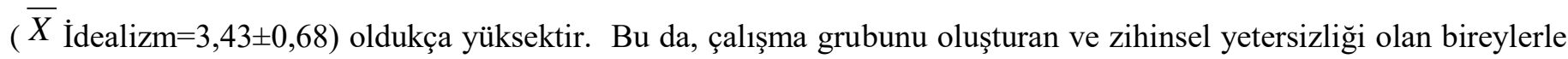
çalışan öğretmenlerin kendilerini idealizm etik değerlerine daha yakın/eğilimli gördüklerini düşündürmektedir. Etik durumlar ile demografik faktörler arasında karşıllaştırma yapıldı̆̆ında ise yalnızca yaş değişkeni ile anlamlı bir farkl11ık bulunduğu görülmektedir. 
Tablo 6. EDÖ alt boyutları puanlarının yaş değişkenine göre farklılaşıp farklılaşmadığını belirlemek üzere yapılan ANOVA testi sonuçları

\begin{tabular}{|c|c|c|c|c|c|c|c|c|c|c|}
\hline \multicolumn{5}{|c|}{$f, \bar{X}$ ve ss Değerleri } & \multicolumn{6}{|c|}{ ANOVA Sonuçları } \\
\hline Puan & Grup & $N$ & $\bar{X}$ & ss & Var. Kay. & $K T$ & $S d$ & $K O$ & $F$ & $p$ \\
\hline \multirow{2}{*}{ İdealizm } & $20-30$ & 205 & 4,05 & 0,48 & G. Arası & 2,77 & 2 & 1,38 & 6,75 & $0,001 *$ \\
\hline & $31-40$ & 95 & 4,25 & 0,36 & G. İçi & 66,82 & 326 & 0,21 & & \\
\hline \multirow{6}{*}{ Görecelik } & 41 yaş ve üstü & 29 & 4,00 & 0,55 & Toplam & 69,58 & 328 & & & \\
\hline & Toplam & 329 & 4,10 & 0,46 & & & & & & \\
\hline & $20-30$ & 205 & 3,41 & 0,65 & G. Arası & 0,38 & 2 & 0,19 & 0,42 & 0,661 \\
\hline & $31-40$ & 95 & 3,48 & 0,74 & G. İçi & 149,55 & 326 & 0,46 & & \\
\hline & 41 yaş ve üstü & 29 & 3,47 & 0,66 & Toplam & 149,93 & 328 & & & \\
\hline & Toplam & 329 & 3,43 & 0,68 & & & & & & \\
\hline
\end{tabular}

Zihinsel yetersizliği olan bireylerle çalışan öğretmenlerin yaşlarına bağlı olarak etik durumlarında anlamlı bir farklılık olup olmadığı tek yönlü varyans analizi (ANOVA) ile incelenmiş ve yaş değişkeninin ölçeğin idealizm alt boyutu bakımından anlamlı bir farklılaşmaya neden olduğu görülmüştür $[\mathrm{F}(2 ; 326)=6,75$ ve $\mathrm{p}<0,05]$ (Tablo 4.24). Hangi yaş grupları arasında anlamlı farklılaşmalar olduğunu araştırmak üzere yapılan post-hoc Scheffe testi sonuçları ise aşağıda, Tablo 7'de verilmiştir.

Tablo 7. İdealizm alt boyutu puanlarının yaş değişkenine göre hangi gruplar arasında farklılaştığını belirlemek üzere yapılan Scheffe testi sonuçları

\begin{tabular}{lllccc}
\hline Puan & \multirow{2}{*}{ Gruplar (i) } & Gruplar (j) & $\bar{X}_{\mathrm{i}}-\bar{X}_{\mathrm{j}}$ & $\mathrm{Sh}_{\overline{\mathrm{x}}}$ & $p$ \\
\hline İdealizm & $20-30$ & $31-40$ &,$- 192^{*}$ & 0,056 & 0,003 \\
& \multirow{2}{*}{$31-40$} & 41 yaş ve üstü & 0,058 & 0,09 & 0,814 \\
& $20-30$ &, $192^{*}$ & 0,056 & 0,003 \\
& 41 yaş ve üstü &, $250^{*}$ & 0,096 & 0,035 \\
& \multirow{2}{*}{ 41 yaş ve üstü } & $20-30$ & $-0,058$ & 0,09 & 0,814 \\
& $31-40$ &,$- 250^{*}$ & 0,096 & 0,035 \\
\hline
\end{tabular}

*Fark $p<.05$ düzeyinde anlamlıdır.

Post-hoc Scheffe testine göre (Tablo 7), 31-40 yaș grubunda bulunan öğretmenlerin idealizm etik düzeleri (puanları), 20-30 ile 41 yaş ve üstü gruplarındaki öğretmenlerden anlamlı bir şekilde daha yüksektir ( $\bar{X}_{20-30=4,05}$; $\bar{X}_{31-40=4,25}$ ve $\bar{X}_{41}$ yaş ve üzeri=4,00).

Tablo 8. Zihinsel yetersizliği olan bireylerle çalışan öğretmenlerin cinsel eğitime yönelik tutumları ile etik durumları arasındaki ilişkiler

\begin{tabular}{|c|c|c|c|c|c|c|}
\hline \multirow{3}{*}{ Boyut/Ölçek } & \multicolumn{6}{|c|}{ Etik Durum Ölçeği } \\
\hline & \multicolumn{3}{|c|}{ İdealizm } & \multicolumn{3}{|c|}{ Görecelik } \\
\hline & $\mathbf{N}$ & $\mathbf{r}$ & $\mathbf{p}$ & $\mathbf{N}$ & $\mathbf{r}$ & $\mathbf{p}$ \\
\hline Akran İlişkileri & 329 &, $154 * *$ & 0,005 & 329 & 0,051 & 0,356 \\
\hline Beden İmgesi & 329 &, $233 * *$ & 0,000 & 329 & 0,024 & 0,666 \\
\hline Gereklilik & 329 &, $121 *$ & 0,028 & 329 & 0,047 & 0,397 \\
\hline Olumsuz Etki & 329 & 0,068 & 0,220 & 329 & $-0,059$ & 0,288 \\
\hline Cinsiyet & 329 & 0,102 & 0,065 & 329 & 0,093 & 0,092 \\
\hline Öğretmen Yeterliliği & 329 &, $123^{*}$ & 0,026 & 329 & $-0,034$ & 0,535 \\
\hline Cinsel Eğitime İlişkin Tutum Ölçeği & 329 &, $183 * *$ & 0,001 & 329 & 0,031 & 0,578 \\
\hline
\end{tabular}


Tablo 8'de araştırmaya katılan öğretmenlerin cinsel eğitime yönelik tutumları ile etik durumları arasındaki ilişkiyi incelemek üzere uygulanan Pearson momentler çarpımı korelasyonuna ait katsayılar sunulmuştur. Değişkenler arasında bulunan ilişkiler (korelasyonlar) aşağıdaki kriterlere göre değerlendirilmiştir;

Tablo 9. Korelasyon kriterleri

\begin{tabular}{ll}
\hline $\mathbf{r}$ & İlişki \\
\hline $0,00-0,25$ & Çok Zayıf \\
$0,26-0,49$ & Zayıf \\
$0,50-0,69$ & Orta \\
$0,70-0,89$ & Yüksek \\
$0,90-1,00$ & Çok Yüksek (Kalaycı, 2006, s.116) \\
\hline
\end{tabular}

Tablodan da takip edilebileceği üzere, zihinsel yetersizliği olan bireylerle çalışan öğretmenlerin cinsel eğitime yönelik tutumları (ölçeğin geneli ve alt boyutları bakımından) ile görece etik değerleri arasında anlamlı bir ilişki yoktur ( $\mathrm{p}>.05)$.

Öğretmenlerin akran ilişkileri alt boyutuna ilişkin algıları/tutumları ile idealizm etik değerleri arasında pozitif yönde ve zayıf bir ilişki vardır ( $\mathrm{r}=0,154$ ve $\mathrm{p}<0,01)$.

Öğretmenlerin beden imgesi alt boyutuna ilişkin algıları/tutumları ile idealizm etik değerleri arasında da pozitif yönde ve zayıf bir ilişki vardır $(r=0,233$ ve $p<0,01)$.

Öğretmenlerin gereklilik alt boyutuna ilişkin algıları/tutumları ile idealizm etik değerleri arasında da yine pozitif yönde ve zayıf bir ilişki vardır ( $r=0,121$ ve $p<0,05)$.

Öğretmenlerin öğretmen yeterliliği alt boyutuna ilişkin algıları/tutumları ile idealizm etik değerleri arasında da pozitif yönde ve zayıf bir ilişki vardır ( $r=0,123$ ve $\mathrm{p}<0,05)$.

Ve son olarak, öğretmenlerin cinsel eğitime yönelik genel tutumlarına (ölçek bazında) ilişkin algıları/tutumları ile idealizm etik değerleri arasında da pozitif yönde ve zayıf bir ilişki vardır $(r=0,183$ ve $p<0,01)$.

\section{Sonuç ve Tartışma}

$\mathrm{Bu}$ çalışma zihinsel yetersizliği olan bireylerle çalışan öğretmenlerin cinsel eğitime yönelik tutumları ile etik durumlarının ilişkisel tarama metoduyla karşılaştııılması amaçlanmıştır. Zihinsel Yetersizliği Olan Bireylerle Çalışan Öğretmenlerin Cinsel Eğitime Yönelik Tutumları Ölçeği sonuçları toplam ortalama puanları genel ve alt boyutları bakımından incelenmiştir. Toplam puanlar bakımından yüksek bir ortalamaya ulaşılmıştır. Buradan hareketle zihin yetersizliği olan bireylerle çalışan öğretmenlerin genel olarak cinsel eğitime yönelik olumlu tutumlar içerisinde oldukları yargısına varılabilir.

Cinsel Eğitime İlişkin Tutum Ölçeği puanlarının farklı değişkenlere göre farklılaşıp farklılaşmadığına dair yapılan değerlendirmelerde branş, çevresinde zihin yetersizliği olan birey bulunma ve çevresinde cinsel istismara uğramış birey bulunma değişkenlerine göre farklılaşırken; cinsiyet, öğrenim durumu, kıdem, cinsel eğitime yönelik ders ya da hizmet içi eğitim alma, 18 yaşına kadar yaşanılan yer ve yaş değişkenlerine göre anlamlı bir fark bulunamamıştır. Bu bulgular Yavuz, Tekcan ve Vural-Batık (2013) tarafından zihin engelliler öğretmenlerinin cinsel eğitime yönelik tutumları incelendiği çalışma ile büyük oranda örtüşmektedir.

Zihinsel yetersizliği olan bireylerle çalışan öğretmenlerin branşlarına bağlı olarak cinsel eğitime yönelik tutumlarında anlamlı bir farklılık olup olmadığı incelenmiş ve branş değişkeninin ölçeğin geneli ile beden imgesi, gereklilik ve öğretmen yeterliliği boyutları bakımından anlamlı bir farklılaşmaya neden olduğu görülmüştür. Hangi branşlar arasında anlamlı farklılaşmalar olduğunu araştırmak üzere yapılan analiz sonuçlarına göre özel eğitim öğretmenleri tüm alt faktörlerde sınıf ve diğer branş öğretmenlerinin puanlarından anlamlı ölçüde yüksek puanlara sahip oldukları görülmektedir. Özel eğitim öğretmenliği müfredatında yer alan zihin yetersizliği olan bireylerin özelliklerini ve ihtiyaçlarını anlatan derslerin yanı sıra bizzat özel gereksinimlilere yönelik tutumların değiştirilmesi ile içeriklendirilmiş bir dersin de bulunması bu noktada özel eğitim öğretmenlerinin tutumlarını olumlu yönde etkilediği düşünülmektedir.

Zihinsel yetersizliği olan bireylerle çalı̧̧an öğretmenlerin çevrelerinde zihinsel yetersizliği olan birey olmasına bağl1 olarak cinsel eğitime yönelik tutumlarında anlamlı bir farklılık olduğu görülmüştür. Öğretmenlerin, çevrelerinde zihinsel yetersizliği olan birey olmasına bağlı olarak cinsel eğitime yönelik genel tutumlarının da anlamlı bir şekilde 
farklı olduğu bulunmuştur. $\mathrm{Bu}$ durum çevresinde zihinsel yetersizliği olan birey olan kişilerin daha fazla empati yapabilmelerinin yanı sıra dolaysız gözlem imkanlarından dolayı özel gereksinimlilerin bu alandaki ihtiyaçlarını daha derinlemesine algılamalarına da olanak sağladığı düşünülmektedir. Diken ve Sucuoğlu'nun (1999) yaptıkları bir çalışma, zihin yetersizliği olan bireylerle yaşantı ve deneyimleri bulunan öğretmenlerin onlara karşı daha olumlu tutum göstermelerine neden olduğu vurgulayarak bu konudaki bulgularımızı desteklemiştir. Benzer şekilde Pala'nın (2008) öğretmen adayları üzerinde yaptığı çalışmada empati düzeyinin artmasının öğrencilere yönelik olumlu tutumları desteklediğini ortaya koymuştur.

Zihinsel yetersizliği olan bireylerle çalışan öğretmenlerin çevrelerinde cinsel istismara uğramış birey olmasına bağlı olarak cinsel eğitime yönelik tutumlarında anlamlı bir farklılık görülmüştür. Yaşar, Şenol ve Akyol'un (2015) yaptığı çalışmada öğretmen adaylarının çocuğa yönelik cinsel istismar tutumları incelenmiştir. Bu araştırmanın sonuçlarında cinsel istismar hikayesi olan katılımcıların tutumlarının daha olumlu olduğu vurgulanmaktadır. Bu sonuç çevresinde cinsel istismara uğramış kişilerin cinsel eğitime yönelik tutumlarının görece daha olumlu olmasını desteklemektedir. Bu bulgu da empatinin tutumlara olumlu etkisini ortaya koyan çalışmalarca da desteklenmektedir (Diken \& Sucuoğlu, 1999; Pala, 2008).

Cinsel Eğitime İlişkin Tutum Ölçeği puanlarının anlamlı fark bulunamayan değişkenlerden özellikle üniversitede ders olarak almak ve bu konuda hizmet içi eğitimlere katılmak gibi faaliyetlerin cinsel eğitime yönelik tutumları etkilememesi oldukça ilgi çekicidir. Tutumların değişimindeki zorlukların bu tabloda pay sahibi oldukları düşünülmektedir. Özyürek’e (2009) göre tutumlar görece dayanıklı, kolay değişkenlik göstermeyen ve kararlı bir yapıdadır.

Etik durum ölçeği analizlerine göre, araştırmaya katılan öğretmenlerin idealizm alt boyutuna ilişkin hesaplanan ortalama puanları görecelik alt boyutu için hesaplanan ortalama puanından oldukça yüksektir. Bu da, çalışma grubunu oluşturan ve zihinsel yetersizliği olan bireylerle çalışan öğretmenlerin kendilerini idealizm etik değerlerine daha yakın/eğilimli gördüklerini düşündürmektedir. İdealizm boyutu yüksek olan kişiler genel olarak davranışlarında başkaları üzerinde yaratacakları etkiyi belirleyici unsur olarak kabul etmektedirler. Onlara göre doğru eylem doğru sonucu yaratır. Görecilik boyutu yüksek olanlar ise zaman ve mekanın bir uzantısı olarak etik kurallara bakmaktadırlar (Forsyth, 1980). Araştırma sonucu, çalışmaya katılan öğretmenlerin doğru eylemin doğru sonucu yaratacağına inanan, eylemlerinin sonuçlarını önemseyen, empati ve özveri sahibi insanlar olduğu kanısını uyandırmaktadır.

Etik Durum Ölçeği puanlarının demografik değişkenlere göre farklılaşıp farklılaşmadığına dair yapılan değerlendirmelerde sadece yaş değişkeni anlamlı bir fark yaratmıştır. Branş, çevresinde zihin yetersizliği olan birey bulunma, çevresinde cinsel istismara uğramış birey bulunma, cinsiyet, öğrenim durumu, kıdem, cinsel eğitime yönelik ders ya da hizmet içi eğitim alma, 18 yaşına kadar yaşanılan yer ve yaş değişkenlerine göre anlamlı bir fark bulunamamıştır. Bu bulgular Duran'ın (2014) okul öncesi öğretmenlerinin etik algıları ile ilgili ve Dağlı ve Akyıldız'ın (2009) ilköğretim denetmenlerinin etik davranışlarıyla ilgili yaptıkları çalışmaların bulgularıyla paralellik göstermektedir.

Zihinsel yetersizliği olan bireylerle çalışan öğretmenlerin cinsel eğitime yönelik tutumları (ölçeğin geneli ve alt boyutları bakımından) ile Etik Durum Ölçeği alt boyutlarından görecelik değerleri arasında anlamlı bir ilişki bulunmamaktadır. Bunula birlikte idealizm alt boyutunda zayıf bir ilişki bulunmaktadır. Buna göre idealizm puanları yüksek olan öğretmenlerin cinsel eğitime yönelik tutum puanları nispeten yüksek çıkmıştır. İdealizm özelliklerinin daha özverili, empatiye açık ve doğru eylemle problemleri ortadan kaldıracağına inanan yapısının bunda rol oynamış olabileceği düşünülmektedir.

\section{Öneriler}

Cinsel eğitime yönelik tutumları daha olumlu hale getirmek için üniversitelerin özel eğitim öğretmenliği bölümlerinde cinsel eğitim dersi zorunlu hale getirilebilir. Sınıf öğretmenliği ve okul öncesi öğretmenlikleri müfredatlarına, özel gereksinimli bireylere yönelik tutumları değiştirmeye yönelik derslerle cinsel eğitim dersleri eklenebilir. Zihinsel yetersizliği olan bireylerle çalışan ancak zihin engelliler öğretmeni olmayan öğretmenlere hizmet öncesi eğitim kapsamında belirli bir süre zihinsel yetersizliği olan bireyleri gözleyebilecekleri bir staj dönemi zorunluluğu getirilebilir. Zihin yetersizliği olan bireylerle çalışan öğretmenlere yönelik cinsel eğitim konusunda bilgilendirme ve 
farkındalık çalışmaları yürütülebilir. Zihinsel yetersizliği olan bireylere yönelik yürütülen bu çalışmaya benzer çalışmalar diğer yetersizlik türlerine yönelik de yürütülebilir. Cinsel eğitime yönelik tutumları etkileyen etik harici faktörlerin neler olabileceğine yönelik çalışmalar yürütülebilir. Zihinsel yetersizliği olan bireylerle çalışan öğretmenlerin tutumlarının sonuçlarının ne olduğuna dair niteliksel araştırmalar desenlenebilir. 


\section{Extended Summary \\ Introduction}

It can be observed that, prior to the age of 18 , the main elements which are regarded as necessary to conclude that there is a significant level of intellectual disability when comparing individuals to peers in many developmental areas (e.g. communication, self-care, social skills), and limitations and inadequacy in adaptive behaviors, are common when the definitions of intellectual disability are examined. The literature does not state that there is a meaningful lack of development in the field of sexual development, which is a basic developmental area, whereas many other areas of developmental delay are mentioned in relevant studies. Furthermore, it is stated in some studies that individuals with intellectual impairment do not significantly differ from their peers in the field of sexual development.

Attitudes of teachers working with intellectual disability individuals gain significance. There are numerous factors which affect these attitudes: social values, moral understandings and commitment to tradition, in short, ethics is a fundamental factor as a whole. When we observe teacher attitudes towards sexual education, some of the teachers who work with intellectual disabilities have a negative attitude. It is thought that the factors affecting the attitudes towards sexual education of teachers working with intellectual disability have to be determined and negative ones must be eliminated while positive ones must be supported in order to reduce the problems in this area. In this context, the significance of ethical values arises.

The main factors determining ethical judgments have been revealed as a result of research conducted. The most dominant of the cited factors are idealism and relativism. Individuals having an idealist education tend to believe that the right actions are required in order to achieve the right results. They act in a way so as not to cause negative consequences and not to harm others when making decisions. Individuals having a predominant tendency of relativism reject the presence of universal and general moral rules.

In this research, answers to the following questions were sought:

1. Do the attitude to sexual education scores of teachers working with intellectually disabled individuals differ significantly according to some variables such as age, gender, field of study, vocational experience, receipt or lack of sexual education instruction and the presence of intellectual disabled persons in the vicinity?

2. Do the ethical situations of teachers working with intellectual disabled individuals differ significantly according to some variables such as age, gender, field of study, vocational experience, receipt or lack of sexual education instruction and the presence of intellectual disabled persons in the vicinity?

3. Is there a meaningful relationship between the attitudes toward sexual education and the ethical status of teachers working with intellectually disabled individuals?

This research is a relational design and this screening modeled study was structured to determine the relations between attitudes toward sexual education and the ethics of teachers working with intellectually disabled individuals. The working group consisted of teachers working in special schools of the Ministry of National Education within eight districts of Istanbul (Kadıköy, Ataşehir, Beykoz, Ümraniye, Şişli, Kağıthane, Zeytinburnu and Bakırköy) and working with intellectually disabled individuals. Within this group, 329 persons were selected by the random inordinate cluster sampling method. These teachers were administered a Personal Data Sheet; an Ethics Status Scale (Cronbach $\alpha$ reliability.90) developed by Forsyth (1980) and adapted to our language, with validity and reliability work carried out by Yazıcı and Yazıcı (2010); and an Attitude Scale Towards Sexual Education for Teachers Working with Individuals with Intellectual Disabilities developed by Serin, Girli and Doğru (2013) (Cronbach $\alpha$ reliability .90).

All data obtained from the teachers participating in the research (Personal Information Form, Attitude Scale Towards Sexual Education and Ethical Status Scale) were analyzed through the SPSS 20.0 for Windows package program. In line with the objective of the research, frequency (f) and percentages (\%) of the variables were calculated in order to summarize the demographic features of teachers constituting the sampling and unrelated groups t-test, oneway variant analysis (ANOVA), post hoc Scheffe, Kruskal Wallis-H test and Pearson moment product correlation analyses were utilized. The significance level was accepted as .05 in all statistical calculations.

It was seen that there was no significant difference in variables such as age, gender, educational status etc. when the demographic variables were compared with the scores of attitudes towards sexual education. It was detected 
that there is a significant difference in some sub-variables such as branch of expertise, presence of individuals who are intellectual disabled in the vicinity and presence of individuals who have been sexually abused in the vicinity.

For the examination of the ethical situation, one-way analysis of variance (ANOVA) was employed in order to determine if there was a significant difference in the ethical status of teachers working with intellectual disabled individuals in terms of their ages and it was observed that the age variable caused a significant difference in the scale of the idealism sub-dimension. No significant differences could be observed in other variables.

There is no significant relation between the attitudes towards sexual education of teachers working with intellectual disabled individuals (in terms of the scale in general and its sub-dimensions) and the sub-dimensions of the Ethics Scale in terms of relativity values. However, there is a weak relation in the sub-dimension of idealism.

Examining all the findings, it can be observed that situations such as the presence of individuals who are intellectual disabled in the vicinity and the presence of individuals who have been sexually abused in the vicinity affect attitudes toward sexual education. This data is in parallel with other studies revealing the positive effect of empathy on attitudes.

Some of the suggestions made as a result of the research are as follows;

- Sexual education courses could be compulsory in the special education teaching departments of universities, with an eye to making the attitudes towards sexual education more positive.

- An obligatory internship period in which teachers working with intellectually disabled individuals but who are not particularly teachers of intellectually disabled individuals can observe teachers and intellectually disabled individuals for a certain period of time within the context of pre-service training.

- Studies may be conducted concerning which non-ethical factors affect attitudes towards sexual education. 


\section{Kaynakça / References}

Ademi, T. J., Pillay, B. J., \& Esterhuizen, T. M. (2013). Differences in HIV knowledge and sexual practices of learners with intellectual disabilities and non-disabled learners in Nigeria. Journal of the International AIDS Society, 16(17331), 1-9.

Ailey, H. S., Marks, B. A., Crisp, C., \& Hahn, J. E. (2003). Promoting sexuality across the life span for individuals with intellectual and developmental disabilities. The Nursing Clinics of North America, 38(2), 21-33.

Akay, H. G. (1999). Çocuk gelişimi. İstanbul: Esin Yayınevi.

Başaran, İ. E. (1998). Eğitim psikolojisi. Ankara: Aydan Web Tesisleri.

Blanchett, W. J., \& Wolfe, P. S. (2002). A review of sexuality education curricula: Meeting the sexuality education needs of individuals with modarete and severe intellectual disabilities. Research and Practice for Persons with Severe Disabilities, $27(1), 43-57$

Brantlinger, E. A. (1985). Mildly mentally retarded secondary students' information about and attitudes toward sexuality and sexuality education. Education and Training of the Mentally Retarde, 20(2), 99-108.

Coleman, M. E., \& Murph, W. D. (1980). A survey of sexual attitudes and sex education programs among facilities for the mentally retarded. Applied Research in the Mental Retardation, 1, 269-276.

Couwenhoven, T. (2001). Sexuality education; Building a foundation for healthy attitudes. Disability Solutions, 4(5).

Dağlı, A., \& Akyıldız, S. (2009). İlköğretim öğretmenlerinin görüşlerine göre ilköğretim denetmenlerinin etik davranışları. Dicle University Journal of Ziya Gokalp Education Faculty, 13, 27-38.

Duran, K. (2014). Okul öncesi ögrretmenlerinin mesleki etik davranışları algılama düzeylerinin ve etik ikilemleri çözümlemelerinin incelenmesi (Yayınlanmış yüksek lisans tezi). Hacettepe Üniversitesi, Ankara.

Edmonson, B., \& Wish, J. (1975). Sex knowledge and attitudes of moderately retarded males. American Journal of Mental Defieciency, 80, 172-179.

Eripek, S. (2009). Zihinsel yetersizliği olan çocuklar. Ankara: Maya Akademi.

Forsyth, D. R. (1980). A taxanomy of ethical ideologies. Journal of Personality and Social Psychology, 39(1), 175-185.

Garwood, M., \& McCabe, M. (2000). Impact of sex education programs on sexual knowledge and feelings of men with a mild intellectual disability. Education and Training in Mental Retardation and Developmmental Disabilities, 35(3), $269-283$.

Hall, J. E., Morris, H. L., \& Barker, H. R. (1973). Sexual knowledge and attitudes of mentally retarded adolecents. American Journal of Mental Deficiency, 77(6), 706-709.

Jahoda, A., \& Pownall, J. (2014). Sexual understanding, source of information and social networks: The reports of young people with intellectual disabilities and theri nondisabilied peers. Journal of Intellectual Disability Research, 58(5), 430-441.

Karasar, N. (2005). Bilimsel araştırma yöntemi (15. baskı). Ankara: Nobel Yayın Dagıtım.

Mandan-Sürücü, S. (2009). 11-17 yaş orta düzeyde zihin engelli klz ergenlerin temel cinsel bilgi ve cinsel istismarl algılamalarının belirlenmesi (Yayınlanmamış yüksek lisans tezi). Marmara Üniversitesi, İstanbul.

McCabe, M. P., Cummins, R. A., \& Deeks, A. A. (1999). Construction and psychometric proberties of Sexualtiy Scales: Sex knowledge, experience and needs scales for people with intellectual disabilities (Sexken ID), people with physical disabilities (Sexken PD), and the general population (Sexken-GP). Research in Developmental Disabilities, 20(4), $241-254$.

MEB. (2012). Özel Eğitim Hizmetleri Yönetmeliği. Ankara: Resmi Gazete (Sayı: 28360).

Myers, A. L. (2006). Sexuality and people with disabilities, rehabilitation and transition conference: Independence first. The Resource For People With Disabilities. Erişim adresi: www.rfw.org/RehabConference/2006/Sessions/11_Sexuality

Özgüven, G. E. (1997). Cinsellik ve cinsel yaşam. Ankara: PDREM Yayınları. 
Özyürek, M. (2009). Engellilere yönelik tutumların değiştirilmesi. Ankara: Kök Yayıncılık.

Pala, A. (2008). Öğretmen adaylarının empati kurma düzeyleri üzerine bir araştırma. Pamukkale Üniversitesi Ĕgitim Fakültesi Dergisi, 23(23), 13-23.

Poroy, A. (2005). Türkiye'de cinsellik. İstanbul: Alfa Yayınc1lık.

Sayın, U. (2007). Zihinsel engelli çocuğa sahip ebeveynler ile normal gelişim gösteren çocuğa sahip ebeveynlerin 7-15 yaş arası çocuklarının toplumsal cinsiyet rollerine yaklaşım ve görüşlerinin incelenmesi (Yayınlanmamış yüksek lisans tezi). Hacettepe Üniversitesi, Ankara.

Seyyar A. (2008). Özürlülük ĕgitimi - cinsel eğitim. Erişim Adresi: http://www.tsd.org.tr

Sucuoğlu, B. (2009). Zihin engelliler ve ĕgitimleri. Ankara: Kök Yayıncılık.

Tepper, M. S. (2001). Becoming sexually able: Education to help youth with disabilities. Siecus Report, 29(3), 5-13.

Whitehouse, M. A., \& McCabe, M. P. (1997). Sex education programs for people with intellectual disability: How effective are they? Educ Training Ment Retard Dev Disabil., 32(3), 229-240.

Yavuz, M., Tekcan, C. A., \& Vural-Batık, M. (2013). Zihinsel engelliler sınıf öğretmenlerinin cinsel eğitime ilişkin tutumları. 23. Ulusal Özel Ĕgitim Kongresi, 30 Ekim-01 Kasım, Abant İzzet Baysal Üniversitesi, Bolu, Türkiye.

Yazıcı, S. (2001). Felsefeye giriş. Ankara: Alfa Yayınevi.

Yazıcı, A., \& Yazıcı S. (2010). Etik Durum Ölçeği’nin geçerlilik güvenirlik çalışması. Türk Eğitim Bilimleri Dergisi, 8(4), 10011017

Yohalem, L. M. A. (1995). Why do people with mental retardation need sexuality education? Siecus Report, 23(4). Erişim adresi: www.siecus.org/siecusreport/volume23/23-4.pdf

Yurdakul, A. (1999). Engelli ergenler ve cinsel eğitim. İlk Işı k Dergisi, 1. Erişim adresi: http://www.isikozelegitim.com/index.php 